\title{
TRANSFERABLE SKILL DAN PEMAHAMAN KONSEP PADA BLENDED LEARNING TERINTEGRASI TRI KAYA PARISUDHA PADA MATA KULIAH PROBSTAT
}

\author{
I Putu Oktap Indrawan \\ Manajemen Informatika, Politeknik Ganesha Guru Singaraja \\ e-mail: iputuoktapindrawan@gmail.com
}

\begin{abstract}
ABSTRAK
Tujuan penelitian ini antara lain untuk mengetahui: (1) ada tidaknya perbedaan transferable skill mahasiswa sebelum dan sesudah implementasi blended learning terintegrasi tri kaya parisudha; (2) ada tidaknya perbedaan pemahaman konsep mahasiswa sebelum dan sesudah implementasi blended learning terintegrasi tri kaya parisudha. Rancangan penelitian yang digunakan adalah one group pretset-postest design dipilih untuk tujuan mengetahui efektivitas atau pengaruh perlakuan terhadap variabel dependen (Sugiyono, 2013). Dalam penelitian ini satu kelompok subjek diberikan perlakuan blended learning terintegrasi tri kaya parisudha. Hal yang dinilai pada subjek ini adalah nilai transferable skill dan nilai pemahaman konsep mahasiswa. Penilaian nilai transferable skill dan nilai pemahaman konsep mahasiswa dilakukan sebelum implementasi blended learning terintegrasi tri kaya parisudha dilambangkan dengan $\mathrm{O}_{1}$, dan penilaian setelah implementasi blended learning terintegrasi tri kaya parisudha dilambangkan dengan $\mathrm{O}_{2}$. Perbedaan hasil pengukuran yang timbul dianggap sebagai akibat dari blended learning terintegrasi tri kaya parisudha yang diterapkan. Analisis data menggunakan analisis statistik deskriptif untuk mengetahui karakteristik data dan inferensial dengan $t$ pair test yang dikomputasi menggunakan IBM SPSS 20 for WIndows. Hasil penelitian menunjukkan: (1) terdapat perbedaan signifikan nilai transferable skill sebelum dan sesudah blended learning terintegrasi tri kaya parisudha $(p<0,05)$ dengan nilai rerata transferable skill mahasiswa setelah implementasi blended learning terintegrasi tri kaya parisudha $(87,11)$ lebih besar dibandingkan sebelumnya $(55,11)$; (2) terdapat perbedaan signifikan nilai pemahaman konsep sebelum dan sesudah blended learning terintegrasi tri kaya parisudha $(p<0,05)$ dengan nilai rerata pemahaman konsep setelah implementasi blended learning terintegrasi tri kaya parisudha $(87,48)$ lebih besar dibandingkan sebelumnya $(55,46)$.
\end{abstract}

Kata kunci: Blended Learning, Tri Kaya Parisudha, Transferable Skill, Pemahaman Konsep

\begin{abstract}
The purpose of this study was to find out: (1) the difference in transferable skills of students before and after the implementation of blended learning integrated tri kaya parisudha; (2) whether there is a difference in understanding the concept of students before and after the implementation of blended learning integrated tri kaya parisudha. The research design used was one group practice-posttest design chosen for the purpose of knowing the effectiveness or effect of treatment on the dependent variable. In this study one group of subjects was given blended learning integrated tri kaya parisudha. The thing that was assessed in this subject was the transferable skill value and the value of understanding the student concept. The assessment of transferable skill values and students' understanding of concept values is carried out prior to the implementation of blended learning integrated tri kaya parisudha symbolized by 01 , and assessment after the implementation blended learning integrated tri kaya parisudha is represented by O2. Differences in measurement results arising are considered as a result of blended learning integrated tri kaya parisudha implemented. Data analysis used descriptive and inferential statistical analysis with $t$ pair tests if those computed using IBM SPSS 20 for Windows. The results showed: (1) there were significant differences in transferable skill values before and after tri-rich integrated blended learning $(p<0.05)$ with student transferable skill scores after the implementation of blended learning integrated tri kaya parisudha $(87,11)$ compared to before (55,11); (2) there is a significant difference in the value of conceptual understanding before and after tri-rich and integrated blended learning $(p<0.05)$ with a mean understanding of concepts after the implementation blended learning integrated tri kaya parisudha $(87.48)$ is greater than before $(55,46)$.
\end{abstract}

Keywords: Blended Learning, Tri Kaya Parisudha, Transferable Skill, Understanding of Concepts 


\section{PENDAHULUAN}

Kementerian Riset, Teknologi, dan Pendidikan Tinggi menekankan perlunya penguasaan teknologi informasi dan komunikasi, terutama bagi kalangan civitas akademika di Era Revolusi 4.0 [1]. Pendidikan tinggi di Indonesia mestinya bergerak maju dengan melaksanakan Pendidikan Jarak Jauh (PJJ) dan pembelajaran daring yang bertujuan mengantisipasi cepatnya perkembangan dunia [2]. Hal tersebut memberikan indikasi supaya semua perguruan tinggi di Indonesia mulai menyiapkan diri mengimplementasikan pembelajaran daring. Persiapan tersebut dapat dimulai dari implementasi pembelajaran semi daring atau blended learning. Implementasi blended learning dalam proses pembelajaran di lingkungan perguruan tinggi, bertujuan untuk membiasakan mahasiswa sebagai bagian dari civitas akademika menggunakan teknologi informasi dan komunikasi dalam kehidupan sehari-hari, yang merupakan salah satu keterampilan penting saat mereka masuk ke dunia kerja [3]. Keterampilan pemanfaatan internet di dunia kerja misalnya e-mail, cloud data, online form, video conference dan group social media mestinya sedari perkuliahan di perguruan tinggi sudah dibiasakan penggunaanya, khususnya diintegrasikan dalam proses pembelajaran.

Permenristekdikti No. 44 Tahun 2015 menyatakan bahwa pembelajaran adalah proses interaksi mahasiswa dengan dosen dan sumber belajar pada suatu lingkungan belajar. Blended learning memungkinkan interaksi antara dosen dan mahasiswa terjadi melalui proses tatap muka maupun secara daring (online) begitu juga dengan sumber belajar. Sumber belajar berupa modul, buku ajar, dan media pembelajaran misalnya slide powerpoint yang dahulu biasanya dicetak atau difotokopi oleh mahasiswa, dengan implementasi blended learning dapat dikirim dan diunduh secara digital oleh mahasiswa sehingga mengurangi pemanfaatan kertas yang tidak perlu.

Fasilitas Politeknik Ganesha Guru sudah memenuhi untuk pengimplementasian Blended learning. pada mahasiswa. Fasilitas internet WiFi di lingkungan kampus memungkinkan pelaksanaan blended learning. Selain itu, masing-masing mahasiswa memiliki laptop dan ponsel android yang memungkinkan perambahan internet dimanapun mereka berada. Data awal hasil pertanyaan terbuka pada pertemuan pertama perkuliahan Mata Kuliah Statistik dan Probabilitas menunjukkan hampir semua mahasiswa memiliki alokasi dana untuk membeli paket data per bulannya, yang digunakan untuk bermedia sosial maupun mencari sumber informasi dalam pembuatan tugas mata kuliah. Mahasiswa menyatakan dalam proses pembelajaran masih belum optimal pemanfaatan internet oleh dosen. Mahasiswa memberikan masukan proses pembelajaran khususnya proses penilaian seperti kuis, tes, dan penugasan sebaiknya memanfaatkan internet sehingga bisa diakses kapan saja dan dimana saja. Selain itu, nilai kuis dan tes dapat dilihat langsung sesudah tes selesai dilakukan. Hal tersebut menunjukkan mahasiswa siap dan antusias melaksanakan blanded learning. Mahasiswa merupakan generasi milenial yang sudah terbiasa mencari informasi, bermain game dan bersosialisasi di dunia maya. Mestinya keterampilan mahasiswa dalam penggunaan internet diarahkan pada kegiatan yang bermanfaat dan benar dalam proses blended learning, sehingga menjadi bagian pengembangan keterampilan hidup.

Blended learning dapat didefinisikan sebagai kombinasi dari metode pembelajaran tradisional dan pembelajaran daring [4]. Metode tradisional termasuk interaksi tatap muka dengan dosen. Pembelajaran tradisional dosen adalah pembicara aktif, sedangkan dalam pembelajaran daring mahasiswa adalah pusat proses belajar mengajar untuk mencapai keragaman kurikulum. Blended learning tidak hanya menggunakan satu media penyampaian pembelajaran melainkan menggabungkan berbagai peluang pembelajaran yaitu daring dan tatap muka [5]. Randy Garrison dan Heather Kanuka dalam [6] telah mendefinisikan blended learning adalah "the thoughtful integration of classroom face-to-face learning experiences with online learning experiences". Jadi blended learning adalah integrasi penuh pengalaman belajar di kelas dengan pengalaman belajar daring yang diberikan kepada pebelajar, untuk pengembangan pengalaman belajarnya. Blended learning dalam penelitian ini adalah mengkombinasikan antara pembelajaran tatap muka dan pembelajaran daring ( $e$ learning) menggunakan kelas maya schoology. Blended learning tidak akan menghasilkan pembelajaran yang lebih baik kecuali jika guru dapat didorong untuk berpikir ulang dan mendesain ulang rencana pembelajaranya sehingga memberikan siswa lebih banyak pengalaman belajar, tentunya yang berbeda dari yang ditawarkan baik secara daring atau di kelas saja. Blended learning mestinya terintegrasi antara komponen daring dan kelas [7]. Blended learning telah digambarkan sebagai mode pengajaran yang menghilangkan hambatan waktu, tempat, dan situasi, sementara memungkinkan interaksi berkualitas tinggi antara guru dan siswa [7]. 
Implementasi blended learning dalam penelitian ini diintegrasikan Tri Kaya Parisudha yang proses pembelajarannya berpusat pada mahasiswa. Tri Kaya Parisudha adalah salah satu kearifan lokal yang dimiliki masyarakat Hindu di Bali yang dapat diimplementasikan di semua ranah kehidupan, salah satunya di dunia pendidikan. Trikaya parisudha terdiri atas manacika (berpikir yang benar), kayika (berbuat benar), dan wacika (berkata yang benar) [8]. Blended learning yang terintegrasi Tri Kaya Parisudha dalam penelitian ini dilakukan implamantasi: (1) manacika, mahasiswa diberikan pertanyaan terbuka tentang materi probabilitas dan statistik yang menstimulasi pemikiranya untuk menjawab dengan mencari informasi sebanyak-banyaknya, menganalisis, dan melakukan generalisasi dari berbagai informasi yang diperoleh; (2) wacika, mahasiswa mendiskusikan hasil temuan, permasalahan, dan hasil kerjanya sehingga dapat berbagi masukan dan kritik untuk proses penyempurnaan; (3) kayika, mahasiswa membuat kuesioner dengan google form, mengambil data, membuat tabel sebaran frekuensi, dan melakukan analisis statistik. Blended learning yang terintegrasi tri kaya parisudha ini tidak hanya mengarahkan cara berpikir, berbuat, dan berkata yang benar (ilmiah) namun juga baik, sesuai dengan nilai-nilai etika yang berlaku. Implementasi blended learning yang terintegrasi tri kaya parisudha diharapkan mampu meningkatkan transeferable skill dan hasil belajar.

Transferable skill adalah keterampilan dan kemampuan yang relevan dan bermanfaat di berbagai bidang kehidupan: sosial, profesional, dan di sekolah [9]. Transferable skill yang ditingkatkan penelitian ini antara lain: (1) research and analytical skills yaitu kemampuan membuat instrumen penelitian, pengambilan data, tabulasi data, analisis data dan interpretasi data; (2) numeracy skills yaitu kemempuan yaitu keterampilan menghitung nilai rerata, median, modus, kuartil, desil, persentil, standar deviasi dan varian yang merupakan bagian dari statistik deskriptif; (3) information and technology skill yaitu keterampilan menggunakan perangkat lunak pengolah kata, spreadsheet, dan perangkat lunak berbasis web seperti schoology, google drive, serta google form.

Hasil belajar merupakan Pemahaman konsep merupakan kompetensi dalam menjelaskan keterkaitan antar konsep dan mengaplikasi konsep atau algoritma secara luwes, efisien, akurat dan tepat dalam pemecahan masalah [10]. Pemahaman konsep dapat dilihat dari kemampuan: (1) menyatakan ulang konsep yang telah dipelajari, (2) mengidentifikasi sifat-sifat operasi atau konsep, serta menerapkan konsep secara logis, (3) menyajikan konsep dalam berbagai macam bentuk representasi matematis (tabel, grafik, diagram, gambar, sketsa, model matematika, atau cara lainnya), [11]. Pemahaman konsep yang akan ditingkatkan dalam penelitian ini antara lain kemampuan: (1) menjelaskan konsep dasar teoritik probabilitas dan statistik; (2) mengumpulkan, mentabulasi, dan menampilkan data dengan benar dans sesuai kebutuhan; dan (3) menganalisis data statistik (secara manual maupun komputasi dengan software) serta menginterpretasikannya.

Tujuan penelitian ini antara lain untuk mengetahui: (1) ada tidaknya perbedaan transferable skill mahasiswa sebelum dan sesudah implementasi blended learning terintegrasi tri kaya parisudha; (2) ada tidaknya perbedaan pemahaman konsep mahasiswa sebelum dan sesudah implementasi blended learning terintegrasi tri kaya parisudha.

\section{METODE}

Metode penelitian yang digunakan adalah pre-experimental design yaitu one-group pretestpostest design [12]. Rancangan ini dapat digambarkan seperti Gambar 01.

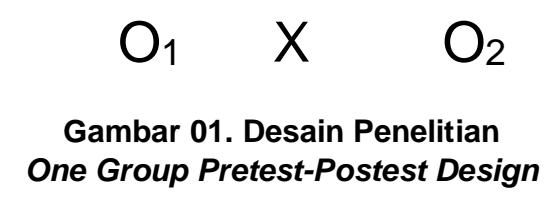

Rancangan one group pretset-postest design dipilih untuk tujuan mengetahui efektivitas atau pengaruh perlakuan terhadap variabel dependen (Sugiyono, 2013). Dalam penelitian ini satu kelompok subjek diberikan perlakuan blended learning terintegrasi tri kaya parisudha. Hal yang dinilai pada subjek ini adalah nilai transferable skill dan nilai pemahaman konsep mahasiswa. Penilaian nilai transferable skill dan nilai pemahaman konsep mahasiswa dilakukan sebelum implementasi blended learning terintegrasi tri kaya parisudha dilambangkan dengan $\mathrm{O}_{1}$, dan penilaian setelah implementasi blended learning terintegrasi tri kaya parisudha dilambangkan dengan $\mathrm{O}_{2}$. Perbedaan hasil 
pengukuran yang timbul dianggap sebagai akibat dari blended learning terintegrasi tri kaya parisudha yang diterapkan.

Populasi penelitian ini adalah mahasiswa Politeknik Ganesha Guru yang mengambil Mata Kuliah Probabilitas dan Statistik yang berjumlah 45 orang. Metode sampel yang digunakan adalah purposive sampling dengan memilih kelas dengan jumlah yang lebih sedikit untuk mempermudah proses observasi dan membimbing setiap mahasiswa yang belajar blended learning, karena projek akhir yang diberikan kepada mahasiswa bersifat individu. Kelas yang digunakan sebagai sampel terdiri atas 15 orang mahasiswa.

Instrumen yang digunakan dalam penelitian antara lain lembar observasi transferable skill dan tes pemahaman konsep. Data dikualifikasikan dengan PAP yang mastery learning seperti Tabel 1 [13].

Tabel 1. Pedoman Konversi Nilai Absolut Skala Lima

\begin{tabular}{ll}
\hline Kreteria & Kualifikasi \\
\hline $90-100$ & Sangat Baik \\
$80-89$ & Baik \\
$65-79$ & Cukup \\
$55-64$ & Kurang \\
$0-54$ & Sangat Kurang \\
\hline
\end{tabular}

Analisis data yang akan dilakukan adalah analisis statistik deskriptif dan inferensial dengan $t$ pair test jika data terdistribusi normal, jika tidak berdistribusi normal akan diuji dengan wilcoxcon sign rank test yang dikomputasi menggunakan IBM SPSS 20 for WIndows.

\section{HASIL DAN PEMBAHASAN}

\section{A. Perbedaan transferable skill mahasiswa sebelum dan sesudah implementasi blended learning terintegrasi tri kaya parisudha}

Data transferable skill sebelum dan sesudah implementasi blended learning terintegrasi tri kaya parisudha ditunjukkan pada Tabel 2 berikut.

Tabel 2. Data transferable skills

\begin{tabular}{cccccr}
\hline Kreteria & Kualifikasi & \multicolumn{2}{c}{ Sebelum } & \multicolumn{2}{c}{ Sesudah } \\
\cline { 3 - 6 } & & $\begin{array}{c}\text { Frekuensi } \\
\text { absolut }\end{array}$ & $\begin{array}{c}\text { Frekuensi } \\
\text { relatif (\%) }\end{array}$ & $\begin{array}{c}\text { Frekuensi } \\
\text { absolut }\end{array}$ & $\begin{array}{r}\text { Frekuensi } \\
\text { relatif (\%) }\end{array}$ \\
\hline $90-100$ & Sangat Baik & 0 & 0.00 & 8 & 53.33 \\
$80-89$ & Baik & 3 & 20.00 & 5 & 33.33 \\
$65-79$ & Cukup & 4 & 26.67 & 1 & 6.67 \\
$55-64$ & Kurang & 2 & 13.33 & 1 & 6.67 \\
$0-54$ & Sangat Kurang & 6 & 40.00 & 0 & 0.00 \\
\hline
\end{tabular}


Berdasarkan Tabel 2 dapat dilihat sebelum implementasi blended learning terintegrasi tri kaya parisudha $40 \%$ mahasiswa nilai transferable skill masuk kualifikasi sangat kurang. Belum ada yang masuk kualifikasi sangat baik. Sesudah implementasi blended learning terintegrasi tri kaya parisudha nilai transferable skill mahasiswa 53\% masuk kualifikasi sangat baik, 33\% kualifikasi baik, dan sisanya masuk kualifikasi cukup dan kurang. Terjadi peningkatan nilai transferable skill sesudah implementasi blended learning terintegrasi tri kaya parisudha.

Sebelum dilakukan analisis statistik inferensial, terlebih dahulu dilakukan uji normalitas sebaran data. Hasil uji normalitas sebaran data transferable skill ditunjukkan pada Tabel 4.

Tabel 4. Hasil uji normalitas data transferable skill

\begin{tabular}{lcc}
\hline & \multicolumn{2}{c}{ Kolmogorov-Smirnov ${ }^{\mathrm{a}}$} \\
\cline { 2 - 3 } & Statistik & $\mathrm{p}$ \\
\hline Sebelum & 0.184 & 0.184 \\
Sesudah & 0.192 & 0.140
\end{tabular}

Hasil uji normalitas sebaran data menggunakan uji Kolmogorov-Smirnov menunjukkan nilai $p<0,05$. Artinya, sebaran data test transferable skill normal sehingga uji inferensial yang digunakan adalah uji statistik parametrik $t$ pair test. Hasil $t$ pair test ditunjukkan pada Tabel 5 berikut.

Tabel 5. Hasil t pair test transferable skill

\begin{tabular}{lcccc}
\hline & Rerata & SD & $t$ & $p$ \\
\hline Sebelum & 55.111 & 23.063 & 6.269 & 0.000 \\
Sesudah & 87.111 & 10.370 & & \\
\hline
\end{tabular}

Berdasarkan Tabel 5 hasil $t$ pair test data transferable skill menunjukkan hasil nilai $p<0,05$, artinya terdapat perbedaan signifikan nilai transferable skill sebelum dan sesudah blended learning terintegrasi tri kaya parisudha. Nilai rerata setelah implementasi $(87,11)$ lebih besar dibandingkan sebelumnya $(55,11)$.

Sebelum implementasi blended learning terintegrasi tri kaya parisudha hasil observasi transferable skill mahasiswa sebagian besar $(40 \%)$ menunjukkan belum mampu dan memahami cara membuat instrumen penelitian, cara pengambilan data, membuat tabulasi data, melakukan analisis data dan kemampuan menginterpretasikan data. Selain itu, numeracy skills dibidang statistik juga masih rendah, $20 \%$ ada yang sudah melakukan perhitungan dasar menggunakan jumlah data sedikit, kemampuan ini mereka peroleh saat mengikuti pelajaran matematika SMA. Keterampilan menghitung statistik deskriptif dari tabel frekuensi belum diketahui. Keterampilan menggunakan perangkat lunak pengolah kata, dan spreadsheet sebagian besar sudah dikuasai mahasiswa, sedangkan keterampilan menggunakan perangkat lunak berbasis web seperti schoology, google drive, serta google form masih perlu dikembangkan lagi.

Implementasi blended learning terintegrasi tri kaya parisudha memperhatikan data observasi transferable skill sebelumnya. Implementasi blended learning terintegrasi tri kaya parisudha untuk meningkatkan transferable skill antara lain:

(1) Research and analytical skills: (a) manacika, mahasiswa mencari teori tentang jenis-jenis instrument dan cara membuat instrument menggunakan google form, teori dan contoh pengambilan data, tabulasi data, analisis data dan cara interpretasi data. Materi dan pertanyaan kuis per pertemuan dilakukan secara daring menggunakan schoology. Hanya sedikit teori yang disampaikan dosen, sebagian besar mahasiswa menggali dan mencari sendiri pengetahuan yang mereka perlukan secara mandiri; (b) kayika, mahasiswa diberikan tugas membuat instrument berupa kuesioner menggunakan google form, mengambil data responden minimal 30 orang, kemudian mentabulasi data tersebut, melakukan analisis dan merepresentasikanya; dan (c) 
wacika, setiap permasalahan dan keraguan dari proses dan data yang diperoleh mahasiswa didiskusikan di dalam kelas, jika waktu tidak memungkinkan diskusi dilanjutkan secara dari menggunakan schoology.

(2) Numeracy skills: (a) manacika, mahasiswa mencari teori, formula, dan contoh perhitungan statistik deskriptif, mengirimkan rangkuman dan contoh perhitungan melalui schoology; (b) kayika, mahasiswa diberikan projek, membuat instrument dengan google form, mentabulasi, menghitung statistik deskriptifnya, dan menginterpretasikan hasil perhitungan tersebut yang dilaporkan dalam satu berkas secara online melalui schoology; (c) wacika, beberapa permasalahan yang dihadapi mahasiswa dalam perhitungan menggunakan rumus statistik baik secara manual atau menggunakan Microsoft Excel didiskusikan bersama di dalam kelas, semua mahasiswa berhak mengemukakan permasalahan, member masukan, dan pendapat. Dosen hanya berperan sebagai fasilitator dan mengklarifikasi apabila ada miskonsepsi.

(3) Information and technology skill: (a) wacika, pada pertemuan awal perkuliahan mahasiswa diberikan RPS dan Information and technology skill yang akan dikembangkan dalam perkuliahan. Mahasiswa disuruh mempelajari penggunakaan beberapa aplikasi yang akan dimanfaatkan dalam perkuliahan antara lain perangkat lunak pengolah kata, spreadsheet, schoology, google drive, dan google form; (b) kayika, pada proses pembelajaran semua mahasiswa ditugaskan membuat kuesioner menggunakan google form membuat link singkat yang di unggah di Schoology agar dapat dibuka oleh dosen dan mahasiswa lainya. Mahasiswa belajar mengekspor hasil pengambilan data berupa .csv yang disimpan di google drive, mengolahnya menggunakan microsoft excel mulai dari pembuatan tabel frekuensi, grafik, dampai dengan analisis deskripftif. Hasil analisis tersebut kemudian dilaporkan dalam bentuk .doc yang dikirim ke assignment shoology dengan batas rentang waktu yang telah disepakati dosen dan mahasiswa.

Sesudah implementasi blended learning terintegrasi tri kaya parisudha hasil observasi transferable skill peningkatan nilai dari sebelumnya yaitu $53 \%$ masuk kualifikasi sangat baik, 33\% kualifikasi baik, dan sisanya masuk kualifikasi cukup dan kurang. Implementasi blended learning terintegrasi tri kaya parisudha berhasil meningkatkan nilai transferable skill dari rerata 55,11 menjadi 87.11. Terjadi peningkatan nilai transferable skill sesudah implementasi blended learning terintegrasi tri kaya parisudha $58,07 \%$ dari nilai sebelumnya.

Penggunaan berbagai sumber daya blended learning untuk memenuhi kebutuhan kritis peserta didik tidak hanya harus fokus pada apa yang sudah ketinggalan zaman tetapi juga apa yang telah terbukti atau memiliki janji untuk melibatkan peserta didik dan mengarah pengetahuan, keterampilan/skill, dan sikap yang diinginkan [5]. Lingkungan belajar blended learning disarankan memberikan gabungan pengalaman pembelajaran daring dan tatap muka yang mendukung pencapaian pengetahuan, keterampilan, dan sikap atau peningkatannya [5]. Pembelajaran blended learning yang mengkombinasikan antara pembelajaran tatap muka dengan pembelajaran daring. Pembelajaran daring (e-learning) merupakan pembelajaran yang dilakukan dengan menggunakan teknologi internet, intranet, dan berbasis web yang memungkinkan terjadinya interaksi belajar antara peserta didik dan pendidik dengan mengakses informasi dan materi pelajaran kapanpun dan dimanapun. Hasil belajar di pendidikan vokasi yang ditekankan adalah keterampilan baik umum maupun khusus. Salah satu keterampilan yang saat ini dikembangkan di dunia vokasi yang menyiapkan lulusan yang siap kerja adalah $c$ yang sering juga disebut life skill. Transferable skill dibutuhkan di dunia kerja maupun di kehidupan sehari-hari. Kebutuhan transferable skill digambarkan sebagai kecenderungan alami seseorang atau kecenderungan untuk menggunakan keterampilan atau pengetahuan seseorang dalam memutuskan dan bertindak apa yang harus dilakukan dalam keadaan apa pun [14].

\section{B. Perbedaan pemahaman konsep mahasiswa sebelum dan sesudah implementasi blended learning terintegrasi tri kaya parisudha}

Data pemahaman konsep sebelum dan sesudah implementasi blended learning terintegrasi tri kaya parisudha ditunjukkan pada Tabel 3 berikut. 
Tabel 3. Data pemahaman konsep

\begin{tabular}{|c|c|c|c|c|c|}
\hline \multirow[t]{2}{*}{ Kreteria } & \multirow[t]{2}{*}{ Kualifikasi } & \multicolumn{2}{|c|}{ Sebelum } & \multicolumn{2}{|c|}{ Sesudah } \\
\hline & & $\begin{array}{c}\text { Frekuensi } \\
\text { absolut }\end{array}$ & $\begin{array}{l}\text { Frekuensi } \\
\text { relatif (\%) }\end{array}$ & $\begin{array}{c}\text { Frekuensi } \\
\text { absolut }\end{array}$ & $\begin{array}{l}\text { Frekuensi } \\
\text { relatif (\%) }\end{array}$ \\
\hline $90-100$ & Sangat Baik & 0 & 0.00 & 8 & 53.33 \\
\hline $80-89$ & Baik & 4 & 26.67 & 5 & 33.33 \\
\hline $65-79$ & Cukup & 4 & 26.67 & 1 & 6.67 \\
\hline $55-64$ & Kurang & 0 & 0.00 & 1 & 6.67 \\
\hline $0-54$ & Sangat Kurang & 7 & 46.67 & 0 & 0.00 \\
\hline
\end{tabular}

Tabel 3 menunjukkan nilai pemahaman konsep sebelum implementasi blended learning terintegrasi tri kaya parisudha 46,67\% masuk kualifikasi sangat kurang, 26,67\% masuk kualifikasi cukup dan $26,67 \%$ masuk kualifikasi baik. Nilai pemahaman konsep sesudah implementasi blended learning terintegrasi tri kaya parisudha $53,33 \%$ masuk kualifikasi sangat baik, 33,33\% masuk kualifikasi baik dan sisanya masuk kualifikasi kurang dan sangat kurang. Dari sebaran frekuensi data tersebut menunjukkan adanya peningkatan nilai pemahaman konsep mahasiswa, yang sebelumnya didominansi kualifikasi sangat kurang menjadi didominansi nilai dengan kualifikasi sangat baik. Rerata nilai pemahaman konsep mengalami peningkatan dari sebelumnya 55,46 menjadi 87,48. Uji normalitas sebaran data pemahaman konsep dilakukan sebelum analisis statistik inferensial. Hasil uji normalitas sebaran data pemahaman konsep ditunjukkan pada Tabel 6.

Tabel 6. Hasil uji normalitas data pemahaman konsep

\begin{tabular}{lcc}
\hline & \multicolumn{2}{c}{ Kolmogorov-Smirnov ${ }^{\mathrm{a}}$} \\
& Statistik & $\mathrm{P}$ \\
\hline Sebelum & 0.216 & 0.059 \\
Sesudah & 0.177 & $0.200^{*}$ \\
\hline
\end{tabular}

Hasil uji normalitas sebaran data menggunakan uji Kolmogorov-Smirnov menunjukkan nilai $p<0,05$. Artinya, sebaran data pemahaman konsep normal sehingga uji inferensial yang digunakan adalah uji statistik parametrik $t$ pair test. Hasil $t$ pair test ditunjukkan pada Tabel 7 berikut.

Tabel 7. Hasil t pair pemahaman konsep

\begin{tabular}{lcccc}
\hline & & & & \\
& Rerata & SD & $\mathrm{t}$ & $\mathrm{p}$ \\
\hline Sebelum & 55.461 & 23.659 & 6.059 & 0.000 \\
Sesudah & 87.482 & 10.760 & & \\
\hline
\end{tabular}

Berdasarkan Tabel 7 hasil $t$ pair test data pemahaman konsep menunjukkan hasil nilai $p<0,05$, artinya terdapat perbedaan signifikan nilai pemahaman konsep sebelum dan sesudah blended learning terintegrasi tri kaya parisudha. Nilai rerata setelah implementasi $(87,48)$ lebih besar dibandingkan sebelumnya $(55,46)$. Sebelum implementasi blended learning terintegrasi tri kaya parisudha hasil tes pemahaman konsep tentang probabilitas dan statistik mahasiswa $46,67 \%$ masuk kualifikasi sangat 
kurang. Artinya secara umum pemahaman awal mahasiswa terkait materi probabilitas dan statistik masih rendah, hal tersebut dibuktikan dengan rendahnya nilai rerata sebelum implementasi yaitu 55,46 . Berdasarkan pertimbangan tersebut, dalam implementasi blended learning terintegrasi tri kaya parisudha dilakukan:

(1) menyatakan ulang konsep yang telah dipelajari: (a) manacikai dan wacika, secara klasikal dosen berdiskusi tentang konsep-konsep statistic deskriptif dengan mahasiswa, memberikan umpan balik positif terhadap mahasiswa yang mampu menjelaskan ulang konsep dengan bahasa dan pemahamannya sendiri. Secara daring mahasiswa menjawab kuis tentang pemahaman konsep tersebut untuk memperkuat pemahamanya; (b) kayika, selanjutnya mahasiswa diberikan tugas untuk mencari definisi konsep dari beberapa sumber yang berbeda dengan contohnya, dan memahami kenapa konsep tersebut penting, peran konsep yang dipelari terkait dengan data yang diperolehnya dalam pengambilan data. Memahami karakteristik data melalui pemahaman yang benar tentang analisis statistik deskriptif.

(2) mengidentifikasi sifat-sifat operasi atau konsep serta menerapkan konsep secara logis: (a) manacika dosen memberikan gambaran umum tentang konsep dan formula statistik deskriptif, mahasiswa mencari secara daring perbedaan formula yang digunakan berdasarkan perbedaan jenis data, pengolahan data mentah maupun yang sudah masuk tabel sebaran frekuensi; (b) kayika, mahasiswa menganalisis data yang diperolehnya menggunakan formula statistik deskriptif, sesuai jenis data baik data mentah maupun data yang sudah dalam tabel distribusi frekuensi yang hasilnya dikirim secara daring; (b) manacika, beberapa mahasiswa memperoleh hasil yang berbeda saat mengimplementasikan formula, hal tersebut didiskusikan mencari penyebab dan mengklarifikasi miskonsepsi yang terjadi.

(3) menyajikan konsep dalam berbagai macam bentuk representasi matematis (tabel, grafik, diagram, gambar, sketsa, model matematika, atau cara lainnya): (a) manacika, pada perkualiahan pertama mahasiswa ditampilkan beberapa grafik dan tabel, kemudian diberikan pertanyaan tentang makna dari grafik dan tabel tersebut; (b) kayika, setelah mahasiswa memperoleh data dari tugas pembuatan kuesioner menggunakan google form mahasiswa memperoleh tugas membuat tabel sebaran frekuensi, grafik, dan analisis statistic deskriptifnya; (c) wacika, beberapa grafik dan tabel frekuensi yang dihasilkan didiskusikan dengan memperhatikan karakteristik data berdasarkan hasil analisis statistik deskriptif yang dilkukan mahasiswa.

Sesudah implementasi blended learning terintegrasi tri kaya parisudha hasil tes pemahaman konsep terjadi peningkatan nilai dari sebelumnya yaitu $53,33 \%$ masuk kualifikasi sangat baik, 33,33\% masuk kualifikasi baik dan sisanya masuk kualitikasi cukup dan kurang. Implementasi blended learning terintegrasi tri kaya parisudha berhasil meningkatkan nilai transferable skill dari rerata 55,46 menjadi 87,48 . Terjadi peningkatan nilai transferable skill sesudah implementasi blended learning terintegrasi tri kaya parisudha $57,73 \%$ dari nilai sebelumnya.

Hasil penelitian ini relevan dengan [15] yang menemukan bahwa penguasaan konsep peserta didik yang belajar menggunakan blended learning lebih tinggi dibandingkan penguasaan konsep peserta didik yang belajar tanpa menggunakan blended learning. Selain itu, [16] juga menemukan bahwa Implementasi Blended Learning By The Constructive Approach (BLCA) mampu meningkatkan pemahaman konsep dan kemandirian belajar mahasiswa. Blended learning berdasarkan hasil penelitian [15] berpengaruh terhadap penguasaan konsep fisika peserta didik. Blended learning membuat siswa mendapatkan pengembangan pemahaman konsep dan pengetahuan konten yang diperkaya, mereka bisa melihat berbagai dimensi baru dari konten yang mereka pelajari dan mendapatkan pengetahuan praktis yang berguna untuk kehidupanya [17]. Blended learning juga bertujuan untuk membuat pengetahuan pebelajar berkorelasi dengan kemajuan teknologi dan globalisasi, serta meminimalkan kesalahan pengajaran karena pebelajar dapat mencari belajar dari berbagai sumber ajar sehingga miskonsepsi akan berkurang [7]. untuk meningkatkan kualitas, untuk meningkatkan keterpaparan siswa, proses pembelajaran mengajar yang didukung TIK adalah pilihan yang baik. Gabungan e-learning dengan tatap muka (blended learning) membantu: (a) akses yang lebih baik terhadap pemahaman konsep, dan (b) pebelajar mampu mengakses informasi baru terkait materi yang dipelajari lebih banyak di internet [18]. Pengajaran dan pembelajaran dengan blended learning menyediakan lingkungan belajar yang meningkatkan interaksi "real time" dengan bahan pembelajaran, diskusi dengan instruktur dan di antara rekan-rekan, dan fasilitas untuk memberikan umpan balik yang dapat ditindaklanjuti tanpa harus menunggu sampai "pertemuan kelas berikutnya", seperti halnya kasus dengan lingkungan belajar tradisional saja [5]. Hal tersebut memungkinkan 
pebelajar lebih cepat menangani miskonsepsi dan menyempurnakan pemahaman konsep yang dimilikinya. Secara umum dalam blended learning menurut [14] individu dengan kemampuan pemahaman konsep yang lebih besar lebih mungkin untuk memproses isi informasi dengan lebih baik daripada mereka yang memiliki kemampuan pemahaman yang lemah.

\section{SIMPULAN DAN SARAN}

Berdasarkan hasil penelitian dan pembahasan maka dapat disimpulkan beberapa hal antara lain: (1) terdapat perbedaan signifikan nilai transferable skill sebelum dan sesudah blended learning terintegrasi tri kaya parisudha $(\mathrm{p}<0,05)$ dengan nilai rerata transferable skill mahasiswa setelah implementasi blended learning terintegrasi tri kaya parisudha $(87,11)$ lebih besar dibandingkan sebelumnya $(55,11)$; (2) terdapat perbedaan signifikan nilai pemahaman konsep sebelum dan sesudah blended learning terintegrasi tri kaya parisudha $(p<0,05)$ dengan nilai rerata pemahaman konsep setelah implementasi blended learning terintegrasi tri kaya parisudha $(87,48)$ lebih besar dibandingkan sebelumnya $(55,46)$.

Berdasarkan hasil penelitian dan pembahasan maka disarankan beberapa hal sebagai berikut. (1) Pengajar/dosen disarankan mengimplementasikan blended learning terintegrasi tri kaya parisudha sebagai salah satu alternative untuk meningkatkan transferable skill dan pemahaman konsep pebelajar/mahasiswa; (2) Peneliti selanjutnya dapat meneliti pengaruh yang lebih luas dan jumlah sampel yang lebih banyak, serta variabel bebas yang lain.

\section{DAFTAR PUSTAKA}

[1] Kemenristekdikti, "Menristekdikti Luncurkan E-Learning/ Hybrid Learning, Strategi Pendidikan Tinggi untuk Kaum Milenial," 12 Mei 2018. [Online]. Available:

http://belmawa.ristekdikti.go.id/2018/05/12/menristekdikti-luncurkan-e-learning-hybrid-learningstrategi-pendidikan-tinggi-untuk-kaum-milenial/.

[2] B. K. d. K. P. Kemenristekdikti, "Menristekdikti Kumpulkan Pimpinan 90 PTN, Bahas Sistem Pendidikan Jarak Jauh dan Online Learning," 16 April 2018. [Online]. Available: https://ristekdikti.go.id/siaran-pers/menristekdikti-kumpulkan-pimpinan-90-ptn-bahas-sistempendidikan-jarak-jauh-dan-online-learning-2/.

[3] Sujarwo, "Pengembangan Dosen Berkelanjutan," 2018.

[4] K. Kant, "Blended Learning: A Latest Trend in Higher Education," University News, vol. 52, no. 34, 2014.

[5] Jared Keengwe \& Joachim Jack Agamba, Models for Improving and Optimizing Online and Blended Learning in Higher Education, USA: the IGI Global book series Advances in Higher Education and Professional Development, 2015.

[6] Takis Kayalis \& Anastasia Natsina, Teaching Literature at a Distance (Open, Online and Blended Learning), London: Continuum International Publishing Group, 2010.

[7] Jeffrey, L.M., John Milne \& Gordon Suddaby, "Blended Learning: How Teachers Balance the Blend of Online and Classroom Components," Journal of Information Technology Education: Research Volume 13, pp. 121-140, 2014.

[8] Adnyana, P.B. \& Citrawathi, "Model Pendidikan Karakter Berbasis Tri Kaya Parisudha Terintegrasi dalam Pembelajaran di Sekolah Dasar," in Seminar Nasional Riset Inovatif, Indonesia, 2017.

[9] Sgobbi, F. dan Suleman, F, The Value of Transferable Skills, Portugal: University of Brescia, 2012.

[10] Wardani, W. S. K. \& Saidiyah, S., "Daya Juang Mahasiswa Asing," Psympathic Jurnal IImiah Psikologi, vol. 3, no. 2, p. 213-224, 2016.

[11] Permendikbud, Peraturan Menteri Pendidikan dan Kebudayaan No. 103 Tahun 2014, Jakarta, 2014.

[12] Sugiyono, Metode Penelitian Kuntitatif Kualitatif dan Kombinasi (Mixed Method), Bandung: Penerbit Alfabeta, 2013.

[13] I. W. Koyan, Buku Ajar: Statistik Dasar dan Lanjut (Teknik Analisis Data Kuantitatif), Singaraja: 
Prodi PEV Pasca Sarjana UNDIKSHA, 2009.

[14] Khe Foon Hew \& Wing Sum Cheung, Using Blended Learning Evidence-Based Practices, Singapore: Springer, 2014.

[15] Hermawanto, S. Kusairi, Wartono, "Pengaruh Blended Learning terhadap Penguasaan Konsep dan Penalaran Fisika Peserta Didik Kelas X," Jurnal Pendidikan Fisika Indonesia, vol. 9, pp. 6776, 2013.

[16] D. Wahyuningsih, "Implementasi Blended Learning By The Constructive Approach (BLCA) untuk Meningkatkan Pemahaman Konsep dan Kemandirian," (tesis) Universitas Negeri Yogyakarta, Yogyakarta, 2013.

[17] Lalima \& Kiran Lata Dangwal, "Blended Learning: An Innovative Approach," Universal Journal of Educational Research, vol. 5, no. 1, pp. 129-136, 2017.

[18] H. D. Surjono, Membangun Course E-Learning Berbasis Moodle Edisi Kedua, Yogyakarta: UNY Press, 2013.

[19] Ruchi Shivam \& Sunita Singh, "Implementation of Blended Learning in Classroom: A review paper," International Journal of Scientific and Research Publications, vol. 5, no. 11, pp. 369-372, 2015. 